\title{
Phytoconstituent Screening and Antibacterial Activity of the Leaf Extracts from Canarium odontophyllum Miq.
}

\author{
Dayang Fredalina Basri, Nur Hafidzah Mohd Nor \\ School of Diagnostic \& Applied Health Sciences, Faculty of Health Sciences, Universiti Kebangsaan Malaysia, \\ Jalan Raja Muda Abdul Aziz, 50300, Kuala Lumpur, Malaysia \\ Email: dayang@ukm.edu.my
}

Received 3 July 2014; revised 6 August 2014; accepted 5 September 2014

Copyright (C) 2014 by authors and Scientific Research Publishing Inc.

This work is licensed under the Creative Commons Attribution International License (CC BY).

http://creativecommons.org/licenses/by/4.0/

(c) (i) Open Access

\section{Abstract}

Canarium odontophyllum is one of the underutilized fruits among the local community in Sarawak, Malaysia. The leaf extracts from C. odontophyllum $(6.25 \mathrm{mg} / \mathrm{ml}$ to $50 \mathrm{mg} / \mathrm{m})$ were screened against two Gram-positive bacteria (Staphylococcus aureus and Bacillus cereus) and two Gram-negative bacteria (Escherichia coli and Pseudomonas aeruginosa). Extraction of the C. odontophyllum leaves using methanol produced the highest yield $(5.46 \%)$ followed by water $(4.0 \%)$ and acetone $(2.83 \%)$ whereas hexane extracted the lowest yield $(0.98 \%)$. Out of the four bacterial species tested, only $S$. aureus was found to be susceptible towards the $C$. odontophyllum leaves extract. Screening result using agar well diffusion method showed that the antimicrobial activity of the acetone and methanol extracts from $C$. odontophyllum leaves was concentration-dependent towards the growth inhibition of $S$. aureus. The MIC values for both $\mathrm{MeOH}$ and acetone extracts were $0.391 \mathrm{mg} / \mathrm{ml}$. The MBC value of MeOH extract was twice its MIC value whereas the MBC and MIC values of acetone extract against $S$. aureus were the same. Phytochemical analysis showed that acetone, $\mathrm{MeOH}$ and water extracts contain flavonoid, tannin, terpenoid and phenol. These findings conclude that the leaves of $C$. odontophyllum may contain therapeutically-useful compounds against $S$. aureus, which are mostly concentrated in the acetone extract. As such, $C$. odontophyllum have the potential to be developed as an alternative treatment against Staphylococcus aureus-associated skin and soft tissue infections.

\section{Keywords}

Leaves, Canarium odontophyllum, Flavonoid, Saponin, Antibacterial, Agar Well Diffusion, Staphyloccocus aureus, MIC, MBC 


\section{Introduction}

Infectious diseases are transmissible diseases that comprise clinically evident illnesses which result from infection of pathogenic biological agents in an individual host organism. Infectious diseases represent a leading cause of morbidity and mortality worldwide, accounting for more than $26 \%$ of all death with developing countries carrying the major burden [1]. Pathogenic biological agents include some viruses, bacteria, fungi, protozoa and multicellular parasites that have the ability to interact with human being by creating a community and cause an infection which reflected in possession of certain pathogenic factors [2].

Nosocomial infection is known to be a major cause of death and increased morbidity among hospitalized patients. It was reported that the most frequent nosocomial infections are infection of surgical wound, urinary tract and lower respiratory tract infection commonly associated with Staphylococcus aureus, Pseudomonas aeruginosa and Escherichia coli [3]. Besides nosocomial infection, foodborne diseases especially diarrheal diseases, are also an important cause of morbidity and mortality that occur worldwide caused by bacteria such as Bacillus cereus. According to the World Health Report [4], 1.8 million childhood death annually due to acute diarrheal illness which is also a very common illness in developed countries.

Antimicrobial agents or antibiotics are used to prevent, control and reduce the occurrence of the infection. Antibiotics are semi-synthetic or synthetic substances produced by the natural metabolic processes of some microorganisms that can inhibit or destroy other microorganism. The greatest number of antibiotics is derived from bacteria from the genera Streptomyces and Bacillus and molds from genera Penicillium and Cephalosporium [5] whereas only $7 \%$ of antimicrobial metabolites are plant-derived compounds [6]. Currently, the phenomenon of antibiotic resistance is the greatest challenge on the treatment of bacterial infection. The number of bacteria that are resistant toward these antibacterial agents has increased each year where $70 \%$ of the bacteria that cause infections in hospitals are resistant to at least one of the most commonly antibiotic agents [7] [8]. As such, new sources of antimicrobial agents need to be discovered and it has become a worldwide challenge. Many scientists from academic institutions and pharmaceutical companies have made an effort to find and discover novel, safe and effective biologically active compound. One of the approaches is by testing the compound derived from the plant origin.

Plants are found to be an enormous source for variety of bioactive compounds with diverse molecular structure and function. These molecules are primarily derived from the secondary metabolism of plants and were used to protect it against predation by microorganisms, insects and herbivorous [9]. Antibacterial secondary metabolites are usually classified in three large molecule families which are phenolic, terpene and alkaloid [10]. The use of plant as traditional medicine has been discovered for thousands of years and was passed down from generation to generation all around the world. It was estimated that about $80 \%$ of the population in most Asian and African countries used traditional medicine as their part of standard healthcare [11]. Nowadays, physicians have been prescribing many drugs that are either directly isolated from plant or are artificially modified version of natural product. The use of these types of medicine as a safe remedy for diseases of both microbial and non-microbial origin has been supported by World Health Organization [12].

Canarium odontophyllum Miq. belonging to Burseraceae family is a tree that can be found in tropical rainforest of Sarawak, Malaysia. It bears fruit pulp known as “dabai” which is blue-black in colour when ripe and is famous among the people in Sarawak. This fruit is rich in mineral, protein, carbohydrate and fat with high level of total phenolic, flavonoid and anthocyanin which is related to its antioxidant activity [13] [14]. In our recent report, it was shown that the pulp extract from $C$. odontophyllum did not possess antibacterial activity but exhibited antifungal effect against Candida glabrata [15]. Unfortunately, no research has been done on the leaves of C. odontophyllum and this is the preliminary report on the antimicrobial activity from the leaves of $C$. odontophyllum.

Therefore, the present study aimed at evaluating the antimicrobial potential of crude extracts from the leaves of C. odontophyllum against two Gram-positive bacteria and two Gram-negative bacteria.

\section{Materials and Methods}

\subsection{Plant Material}

Fresh leaves of Canarium odontophyllum were obtained from Sarawak, Malaysia and was deposited at the Herbarium Universiti Kebangsaan Malaysia in Bangi, Malaysia with voucher specimen no. UKMB 40052. The 
leaves were dried in the oven and grinded into powdered form using electric grinder. The preparation of extracts from C. odontophyllum leaves was adopted from Basri and Fan [16].

\subsection{Preparation of Organic Extracts}

The powdered $C$. odontophyllum leaves were sequentially extracted by three organic solvents based on the different order of polarity. The hexane extract was prepared by immersing $100 \mathrm{~g}$ of the dried material in $500 \mathrm{ml}$ hexane and shaked at $100 \mathrm{rpm}$ for $24 \mathrm{~h}$ at $50^{\circ} \mathrm{C}$. The mixture was then filtered through Whatman No. 1 filter paper. The residue was further extracted twice by adding $300 \mathrm{ml}$ of fresh solvent each time, after then all the filtrate were combined together. The remaining residue were air-dried and further extracted with acetone, followed by methanol by similar procedure carried out for hexane extraction. The solvent from the combined filtrate was evaporated using rotary evaporator until it formed a pellet. Finally the pellet was pounded to dryness under hot air-dryer to remove the remaining solvent. The final yield of each extract was weighed and stored at $4^{\circ} \mathrm{C}$ until further use.

\subsection{Preparation of Aqueous Extract}

In the preparation of aqueous extract, $100 \mathrm{~g}$ of the powdered leaves were macerated in $500 \mathrm{ml}$ distilled water and shaked at $100 \mathrm{rpm}$ for $24 \mathrm{hr}$ at room temperature. Then the mixture was centrifuged at $3000 \mathrm{rpm}$ for $5 \mathrm{mi}-$ nutes. The supernatant was then filtered and the whole process were repeated using the remaining residue with $300 \mathrm{ml}$ distilled water. The filtrates were combined and freeze-dried at $-50^{\circ} \mathrm{C}$ under vacuum for $24 \mathrm{~h}$ to produce a fine crystal-like crude aqueous extract. The extract was weighted and stored in air-tight jar at $4^{\circ} \mathrm{C}$ until further use.

\subsection{Preparation of Extract Solution}

The extracts were dissolved in their respective solvent to a final concentration of $6.25 \mathrm{mg} / \mathrm{ml}, 12.5 \mathrm{mg} / \mathrm{ml}, 25$ $\mathrm{mg} / \mathrm{ml}$ and $50 \mathrm{mg} / \mathrm{ml}$ for agar-well diffusion method and $100 \mathrm{mg} / \mathrm{ml}$ for broth microdilution technique.

\subsection{Microorganisms}

The bacterial species used in this study were two Gram-positive bacteria (Staphylococcus aureus ATCC 25923 and Bacillus cereus ATCC 6633) and two Gram-negative bacteria (Pseudomonas aeruginosa ATCC 27853 and Escherichia coli ATCC 25922). All the bacterial strains were grown and maintained on nutrient agar slants. The inoculum size of each test strain was $10^{8} \mathrm{CFU} / \mathrm{ml}$ for agar well diffusion assay which was standardized by adjusting the optical density of the bacterial suspension to a turbidity corresponding to spectrophotometric absorbance of $0.08\left(\mathrm{OD}_{620}=0.08\right)$ at $620 \mathrm{~nm}$.

\subsection{Screening for Antibacterial Activity}

The screening of antibacterial activity of $C$. odontophyllum leaves was carried out using agar-well diffusion method based on [15]. In this assay, Mueller-Hinton agar plates were used for the growth of each bacterial species. Each plate was uniformly seeded with bacteria by dipping in the standardized suspension with sterile swab and streaking it on the surface of the agar plate. The wells of $5 \mathrm{~mm}$ in diameter were punched into the inoculated agar media with sterile Pasteur pipette. Each plate for each tested extract comprised six wells to accommodate the extract concentrations at $50 \mathrm{mg} / \mathrm{ml}, 25 \mathrm{mg} / \mathrm{ml}, 12.5 \mathrm{mg} / \mathrm{ml}$, and $6.25 \mathrm{mg} / \mathrm{ml}$ as well as for positive and negative controls. Approximately, $60 \mu \mathrm{l}$ of the extract solution were dropped into each well, respectively. For positive control, vancomycin ( $30 \mu \mathrm{g} / \mathrm{ml}$ ) was used against $S$. aureus, whereas gentamicin $(30 \mu \mathrm{g} / \mathrm{ml})$ was used for $B$. cereus, $P$. aeruginosa and $E$. coli. The extraction solvent for each extract served as negative control. The plates were pre-incubated for $1 \mathrm{hr}$ at room temperature, allowing the complete diffusion of the samples before incubated at $37^{\circ} \mathrm{C}$ for overnight. The antibacterial activity was determined by measuring the diameter of inhibition zone surrounding the well. Each experiment was repeated in triplicate in order to calculate the mean value \pm SD value.

\subsection{Determination of MIC and MBC Values}

Minimum inhibitory concentration (MIC) value of the extracts was determined against the bacterial strains using 
the two-fold serial microdilution method carried out performed in 96-well microtiter plate according to Basri and Khairon [17]. This procedure will only be performed on the extract that showed inhibitory growth against any tested bacteria in agar well diffusion screening test. Initially, the tested extract was added into the well containing the Mueller-Hinton broth followed by addition of the standardized bacterial suspension to make up the final concentration ranging from $25 \mathrm{mg} / \mathrm{ml}$ to $0.049 \mathrm{mg} / \mathrm{ml}$. Each extract was assayed in triplicate. The extract in the broth was used as negative control to ensure medium sterility while the bacterial suspension served as positive control to control the adequacy of the broth for bacterial growth. To visualize the cell viability, $20 \mu \mathrm{l}$ of 3-[4,5-dimethylthiazol-2-yl]-2,5-diphenyltetrazolium bromide (MTT, $1 \mathrm{mg} / \mathrm{ml}$ ) and $20 \mu \mathrm{l}$ of 2,3,5-triphenyltetrazolium chloride (TTC, $2 \mathrm{mg} / \mathrm{ml}$ ) were added into each well containing respectively, Gram-positive and Gramnegative bacterial strains. The minimum bactericidal concentration (MBC) was determined by subculture of the well showing no apparent growth in a sterile agar plate. The least concentration showing no visible growth on agar subculture was taken as the MBC value.

\subsection{Phytochemical Analysis}

The aqueous, acetone and methanol leaf extracts of $C$. odontophyllum were screened for the presence of phytoconstituents based on [18].

\section{Results}

Table 1 showed the percentage yield of hexane, acetone, methanol and water of $C$. odontophyllum leaf extracts. In the extraction of $C$. odontophyllum powdered leaves, methanol showed the highest percentage of extraction yield followed by aqueous and acetone extracts, respectively. Methanol extract was produced from $5.46 \%$ of dried powdered leaves while aqueous and methanol each produced $4.0 \%$ and $2.83 \%$. Hexane appeared to produce the lowest extraction yield of only $0.98 \%$ from the dried powdered leaves.

From the result of antibacterial screening assay (Table 2), only Staphylococcus aureus was susceptible towards acetone and methanol extracts of $C$. odontophyllum leaves. Hexane and aqueous extracts were not capable of inhibiting the growth of all the bacteria tested. Figure 1 illustrated the diameter zones of inhibition by the extracts against $S$. aureus. It can be seen from Table 3 that the mean diameter inhibition zone for methanol extract at $6.25-50 \mathrm{mg} / \mathrm{ml}$ was $7.00 \pm 0.00$ to $22.33 \pm 0.58 \mathrm{~mm}$ whereas acetone extract $(6.25-50 \mathrm{mg} / \mathrm{ml}$ ) recorded bigger mean inhibition zone from $12.00 \pm 0.00$ to $24.33 \pm 0.15 \mathrm{~mm}$. Both acetone and methanol extracts at 25 $\mathrm{mg} / \mathrm{ml}$ displayed stronger inhibitory effect against $S$. aureus $(20.33 \pm 0.58 \mathrm{~mm}$ and $18.67 \pm 0.58 \mathrm{~mm}$, respectively) compared to the positive control (vancomycin $0.03 \mathrm{mg} / \mathrm{ml}$ ) with inhibition zone of $15.00 \pm 0.00 \mathrm{~mm}$. However, acetone extract exhibited significantly bigger $(\mathrm{p}<0.05)$ inhibition zone than the methanol extract at all concentrations studied. The MIC values of the acetone and methanol extracts from $C$. odontophyllum leaves against S. aureus were shown in Table 4. Interestingly, both extracts were found to exhibit similar MIC values against $S$. aureus $(0.391 \mathrm{mg} / \mathrm{ml})$. The MIC values of both extracts correlated to the screening test result. The standard drug used in the study, vancomycin showed MIC value of $0.0075 \mathrm{mg} / \mathrm{ml}$ (Table 5). This means that the MIC values of acetone and methanol extract were about 50 times less potent than standard antimicrobial agent. The MBC values of the methanol and acetone extracts from $C$. odontophyllum leaves against $S$. aureus were tabulated in Table 6. The MBC value for acetone extract was the same as its MIC value which is, $0.391 \mathrm{mg} / \mathrm{ml}$. This showed that the acetone extract have bactericidal effect against $S$. aureus. As for methanol extract, the MBC value was slightly higher $(0.781 \mathrm{mg} / \mathrm{ml})$ compared to MIC value $(0.391 \mathrm{mg} / \mathrm{ml})$ that indicated the methanol have bacteriostatic effect on the bacteria.

The result of phytochemical screening of the extracts of $C$. odontophyllum leaves was shown in Table 7 . The

Table 1. Extraction yield of $C$. odontophyllum leaves using various solvents.

\begin{tabular}{cccc}
\hline Extraction solvent & Fresh sample weight (g) & Extract weight (g) & Percentage of yield (\%) \\
\hline Hexane & 100 & 0.98 & 0.98 \\
Acetone & 100 & 2.83 & 2.83 \\
Methanol & 100 & 5.46 & 5.46 \\
Water & 100 & 4.0 & 4.0 \\
\hline
\end{tabular}


Table 2. Antimicrobial activity of extracts from C. odontophyllum leaves $(6.25 \mathrm{mg} / \mathrm{ml}-50 \mathrm{mg} / \mathrm{ml})$ against four bacterial species.

\begin{tabular}{|c|c|c|c|c|c|}
\hline \multirow{2}{*}{ Extract } & \multirow{2}{*}{$\begin{array}{l}\text { Extract concentration } \\
\qquad(\mathrm{mg} / \mathrm{mL})\end{array}$} & \multicolumn{4}{|c|}{ Diameter of inhibition zone (mm) } \\
\hline & & S. aureus & B. cereus & E. coli & P. aeruginosa \\
\hline \multirow{4}{*}{ Hexane } & 50 & - & - & - & - \\
\hline & 25 & - & - & - & - \\
\hline & 12.5 & - & - & - & - \\
\hline & 6.25 & - & - & - & - \\
\hline \multirow{4}{*}{ Acetone } & 50 & $24.33 \pm 1.15$ & - & - & - \\
\hline & 25 & $20.33 \pm 0.58$ & - & - & - \\
\hline & 12.5 & $17.33 \pm 0.58$ & - & - & - \\
\hline & 6.25 & $12.00 \pm 0.00$ & - & - & - \\
\hline \multirow{4}{*}{ Methanol } & 50 & $22.33 \pm 0.58$ & - & - & - \\
\hline & 25 & $18.67 \pm 0.58$ & - & - & - \\
\hline & 12.5 & $12.33 \pm 0.58$ & - & - & - \\
\hline & 6.25 & $7.00 \pm 0.00$ & - & - & - \\
\hline \multirow{4}{*}{ Water } & 50 & - & - & - & - \\
\hline & 25 & - & - & - & - \\
\hline & 12.5 & - & - & - & - \\
\hline & 6.25 & - & - & - & - \\
\hline \multirow{2}{*}{ Control positive } & Vancomycin $(30 \mu \mathrm{g} / \mathrm{ml})$ & $15.00 \pm 0.00$ & - & - & - \\
\hline & Gentamisin $(10 \mu \mathrm{g} / \mathrm{ml})$ & - & $22.00 \pm 0.00$ & $22.00 \pm 0.00$ & $29.00 \pm 0.00$ \\
\hline \multirow{4}{*}{ Control positive } & Hexane & - & - & - & - \\
\hline & Acetone & - & - & - & - \\
\hline & Methanol & - & - & - & - \\
\hline & Water & - & - & - & - \\
\hline
\end{tabular}

(-): No inhibition of bacterial growth; Positive control comprises vancomycin $(30 \mu \mathrm{g} / \mathrm{ml})$ for S. aureus ATCC 25923 and gentamicin $(30 \mu \mathrm{g} / \mathrm{ml})$ for B. cereus ATCC 6633, E. coli ATCC 27853 and P. aeruginosa ATCC 25922; Negative control comprises respective extraction solvent.

Table 3. Mean diameter of inhibition zones of methanol and acetone extracts from C. odontophyllum leaves against $S$. aureus ATCC 25923.

\begin{tabular}{ccc}
\hline \multirow{2}{*}{ Concentration $(\mathrm{mg} / \mathrm{ml})$} & \multicolumn{2}{c}{ Diameter of inhibition zone (mm) } \\
\cline { 2 - 3 } 50 & Methanol extract & Acetone extract \\
25 & $22.33 \pm 0.58$ & $24.33 \pm 0.15$ \\
12.5 & $18.67 \pm 0.58$ & $20.33 \pm 0.58$ \\
6.25 & $12.33 \pm 0.58$ & $17.33 \pm 0.58$ \\
Vancomycin $(30 \mu \mathrm{g} / \mathrm{ml})$ & $7.00 \pm 0.00$ & $12.00 \pm 0.00$ \\
\hline
\end{tabular}


Table 4. Determination of MIC values of acetone and methanol extracts of $C$. odontophyllum leaves against $S$. aureus ATCC 25923.

\begin{tabular}{|c|c|c|c|c|}
\hline \multirow{3}{*}{ Concentration (mg/ml) } & \multicolumn{4}{|c|}{ S. aureus ATCC 25923} \\
\hline & \multicolumn{2}{|c|}{ Extracts } & \multicolumn{2}{|c|}{ Control } \\
\hline & Acetone & Methanol & Positive & Negative \\
\hline 25 & - & - & + & - \\
\hline 12.5 & - & - & + & - \\
\hline 6.25 & - & - & + & - \\
\hline 3.125 & - & - & + & - \\
\hline 1.563 & - & - & + & - \\
\hline 0.781 & - & - & + & - \\
\hline 0.391 & - & - & + & - \\
\hline 0.195 & + & + & + & - \\
\hline 0.098 & + & + & + & - \\
\hline 0.049 & + & + & + & - \\
\hline
\end{tabular}

$(-)$ : Absence of growth, clear well; $(+)$ : Presence of growth, turbid well; Positive control comprises bacterial suspension and Mueller-Hinton broth; Negative control comprises vancomycin and Mueller-Hinton broth.

Table 5. Determination of MIC value of vancomycin against ATCC 25923.

\begin{tabular}{|c|c|c|c|}
\hline \multirow{2}{*}{ Concentration $(\mu \mathrm{g} / \mathrm{ml})$} & \multicolumn{3}{|c|}{ S. aureus ATCC 25923} \\
\hline & Vancomycin & Positive control & Negative control \\
\hline 7.5 & - & + & - \\
\hline 3.75 & + & + & - \\
\hline 1.875 & + & + & - \\
\hline 0.938 & + & + & - \\
\hline 0.469 & + & + & - \\
\hline 0.234 & + & + & - \\
\hline 0.117 & + & + & - \\
\hline 0.059 & + & + & - \\
\hline 0.029 & + & + & - \\
\hline 0.015 & + & + & - \\
\hline
\end{tabular}

(-): Absence of growth, clear well; (+): Presence of growth, turbid well; Positive control comprises bacterial suspension and Mueller-Hinton broth; Negative control comprises vancomycin and Mueller-Hinton broth.

Table 6. Determination of MBC values of acetone and methanol extracts from C. odontophyllum against S. aureus ATCC 25923.

\begin{tabular}{|c|c|c|c|c|c|c|c|c|c|c|c|}
\hline \multirow{2}{*}{ Bacteria } & \multirow{2}{*}{ Extracts } & \multicolumn{10}{|c|}{ Concentration of the extracts (mg/ml) } \\
\hline & & 25 & 12.5 & 6.25 & 3.125 & 1.563 & 0.781 & 0.391 & 0.195 & 0.098 & 0.049 \\
\hline \multirow{2}{*}{$\begin{array}{c}\text { S. aureus } \\
\text { ATCC } 25923\end{array}$} & Acetone & - & - & - & - & - & - & - & + & + & + \\
\hline & Methanol & - & - & - & - & - & - & + & + & + & + \\
\hline
\end{tabular}

$(-)$ : Absence of growth; $(+)$ : Presence of growth. 
Table 7. Result of phytochemical constituents screening of extracts of $C$. odontophyllum.

\begin{tabular}{cccc}
\hline Test & Methanol extract & Acetone extract & Aqueous extract \\
\hline Alkaloid & - & - & - \\
Flavonoid & + & + & + \\
Saponin & + & + & + \\
Tannin & + & + & + \\
Terpenoid & + & + & + \\
Phenolic compound & + & +
\end{tabular}

(+): Presence of constituent; (-): Absence of constituent.

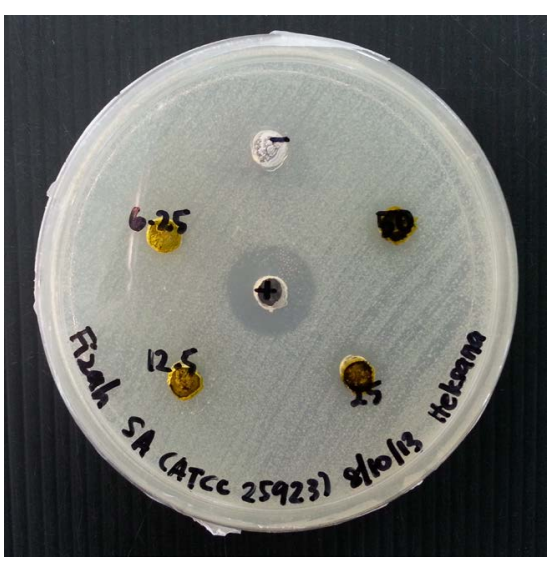

(a) Hexane extract

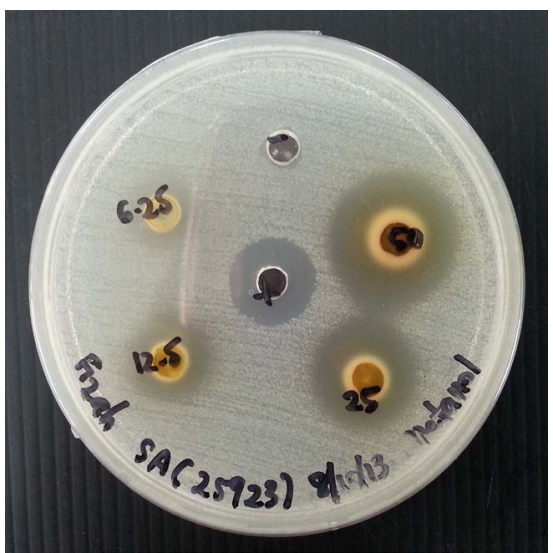

(c) Methanol extract

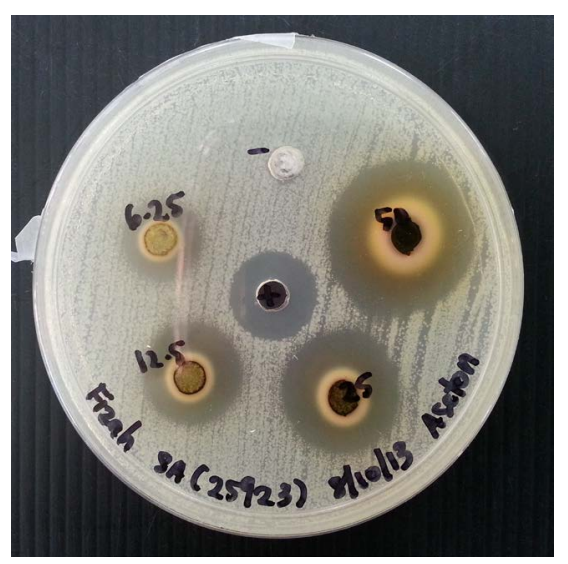

(b) Acetone extract

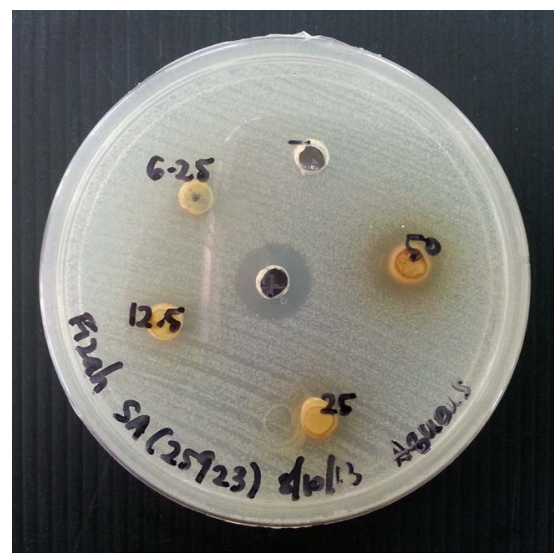

(d) Aqueous extract

Figure 1. Plates showing diameter zone of inhibition by the hexane, acetone, methanol and aqueous extract of $C$. odontophyllum leaves against $S$. aureus.

screening test revealed the presence of terpenoid, tannin, flavonoid and phenol in acetone, $\mathrm{MeOH}$ and aqueous extracts. However, only the aqueous extract did not show the presence of saponin. Alkaloid was not detected in all three extracts from C. odontophyllum leaves.

\section{Discussion}

Solvent with increasing level of polarity namely hexane, acetone, methanol and water were used in this study to extract a wide range of active compounds from the plant. In general, the percentage yield of extraction was 
higher in polar solvent than nonpolar solvent. Nonpolar solvent (hexane) produced a yield of less than $1 \%$ which comprises mostly lipophilic compounds whereas a value of 5.46\% represented the yield obtained when methanol which was the more polar solvent was used. The semipolar solvent used in this study was acetone and it resulted in a medium yield of $2.83 \%$. Methanol resulted in a higher yield when compared to other solvents which was in agreement with [19] which reported that methanol extraction showed a higher yield of polar compounds from Cistus creticus compared to using dicholoromethane. This suggests that there are more polar compounds in $C$. odontophyllum leaves than nonpolar compounds.

Despite higher polarity index for water compared to methanol, aqueous extract however produced lower extraction yield than methanol in this study. This is due to the effect of other solvent properties such as viscosity and vapor pressure on the extraction. According to [20], solvent with low viscosity (methanol $=0.6$ ) can easily penetrate into plant texture due to its low density and high diffusivity compared to liquid with higher viscosity (water $=0.89$ ). In addition to this, the higher vapor pressure of methanol allows the cavitational bubbles formed as a result of its low viscosity, to require less force to collapse, hence less energy is released to disrupt plant tissue [21]. Methanol has a low viscosity compared to water which eases the diffusion of methanol into the pores of the plant materials to extract the compound more effectively compared to other extraction solvent which have the same polarity [22]. Generally, the percentage yield of $C$. odontophyllum leaves decreased in the following order; methanol $>$ water $>$ acetone $>$ hexane. Since the yield of hexane extract was the lowest and showed no antibacterial activity, phytochemical screening was not done on hexane extract from $C$. odontophyllum leaves. Analysis of phytoconstituent testing was performed on methanol, aqueous and acetone leaf extracts from $C$. odontophyllum.

In the screening of antibacterial activity using agar-well diffusion technique, only $S$. aureus was found to be susceptible towards the $C$. odontophyllum leaf extracts. In other words, out of the four bacterial species studied, only S. aureus was found to be susceptible towards the methanol and acetone extracts of $C$. odontophyllum leaves. The methanol and acetone extracts were capable of inhibiting the growth of $S$. aureus whereas no antimicrobial activity against $S$. aureus was recorded by the hexane and aqueous extracts from the leaf of $C$. odontophyllum. This results demonstrated that the non-polar and the most polar solvent were incapable of extracting active anti-S. aureus component from the leaves of Canarium species. The leaf from Canarium schweinfurthii demonstrated inhibitory effect on the growth of $S$. aureus [23] by the ethylacetate extract but not by dicholoromethane. This is further supported by [24] that the hexane extract of C. patentinervium leaves showed no antimicrobial activity. As far as aqueous extract is concerned, this study also implies that the tested $S$. aureus isolates were not very sensitive to the polar compounds of $C$. odontophyllum. This is in accordance with [25] that compared the aqueous extract of the stem bark of Combretum molle with acetone extract against Helicobacter pylori activity, whereby the anti-H. pylori compounds in C. molle were not extracted by polar solvents. It was also reported [26] that absence of antimicrobial activity of the aqueous extract of other plant indicating that water may not be a suitable solvent for the extraction of antimicrobial compounds from the plants despite its high availability and relatively no toxicity. Our finding with acetone extract clearly showed a significantly $(\mathrm{p}<0.05)$ higher inhibitory effect against $S$. aureus compared to methanol extract as observed from the size of the diameter of the inhibition zone at different concentration between the extracts. The diameter of inhibition zones seemed to decrease with an increase in the polarity of the solvent from acetone to methanol. This was probably because the total amount of phenolic compounds such as flavonoid extracted by acetone is much higher compared to methanol despite lower extraction yield compared to methanol. This is in accordance with [27] that acetone was the best solvent for extracting flavonoids from bitter melon out of five solvents (ethanol, methanol, n-butanol, acetone and water). The antimicrobial activity of the methanol and acetone extracts from C. odontophyllum leaves was concentration-dependent towards the growth inhibition of S. aureus ATCC 25923 and this could correlated to the presence of flavonoids in the extracts.

The equal MIC values for both methanol and acetone extracts against $S$. aureus indicated that both extracts exhibited equal antimicrobial potency against the bacteria. However, the MIC values of both extracts did not correlate well with the screening result using agar well diffusion technique. This is because although acetone extract showed a significantly stronger inhibitory effect against $S$. aureus compared to methanol extract, it would be predicted that the MIC value of the acetone extract is lower than the latter but this is not the case. Our observation is in line with [28] whereby the MIC value of methanol and ethyl acetate extracts from Thuja orientalis leaves against Pseudomonas aeruginosa were found to be same despite discrepancy in the inhibitory activity of these extracts in agar well diffusion screening assay. As expected, the MIC values of acetone and metha- 
nol extract of $C$. odontophyllum leaves were dramatically lower than that of vancomycin. The difference may be due to the impurity of these crude extract that might contained a mixture of compound compared to pure compound in standard drug [29].

In screening of new antimicrobial agent, it is very important to characterize the type of antibacterial activity displayed by plant extract. This can be done by comparing MBC value with MIC value of each extract. Current study showed that the MIC and MBC values of acetone extract against $S$. aureus were the same whereas the MBC values of methanol extract was twice its MIC value. This indicated that acetone and methanol crude extract might contain bioactive constituent that respectively, exhibited bactericidal and bacteriostatic action against S. aureus. The bactericidal effect of the acetone extract from the leaves of $C$. odontophyllum was in agreement with [25] which confirmed that acetone extract from Combretum molle exhibited considerable bactericidal activity against Helicobacter pylori. Phytochemical screening from this study showed the presence of flavonoid, terpenoid, tannin, phenoland saponin in both the leaf extracts from Canarium odontophyllum. The anti-S. aureus activity of Canarium odontophyllum was possibly due to its phenolic constituents as suggested by [30] that there is a correlation between total phenolic content and antibacterial activity of the aqueous acetone from the extract of Anogeissus leiocarpus leaves. The leaf extracts from Canarium schweinfurthii also revealed the presence of tannin and saponin which could contributed to its antimycobacterial activity against Mycobacterium tuberculosis [31]. In another study, Canarium album leaves had a relatively high level of total phenolic and extractable condensed tannin [32] whereas ethanol extract of leaves and barks from Canarium patentinervium accumulate substantial amounts of tannin and flavonoid [24]. Flavonoids are known to be synthesized by plants in response to microbial infection [33] [34]. Saponin which was present in the acetone and methanol extract studied, could also account for the antimicrobial activity against $S$. aureus. This is confirmed by [35] that saponin fractions of the leaves of Solanum xanthocarpum and Centella asiatica inhibited the growth of Gram positive bacterium S. aureus. It is pertinent to mention here that saponin was not detected in the aqueous extract from C. odontophyllum leaves studied and this could justify the absence of antimicrobial activity in this extract. This is because the active components in the crude extract may be acting in synergism to produce greater antimicrobial effects [36].

\section{Conclusion}

In conclusion, the acetone extract of $C$. odontophyllum leaves have the potential to be developed as an alternative treatment against Staphylococcus aureus-associated skin and soft tisue infections. However, identification work is necessary to determine the bioactive compound in the extract responsible for the antibacterial activity. Moreover, evaluation of antimicrobial activity potency against a wider range of microorganisms such as clinical isolates of resistant organisms, such as Methicillin-Resistant Staphylococcus aureus (MRSA) is also recommended to obtain a more accurate evaluation of the therapeutic potential of $C$. odontophyllum leaves.

\section{Acknowledgements}

The authors would like to thank Dr. Nor Malia Abdul Warif and Ammar Syatbi Mohd Shabry from Universiti Kebangsaan Malaysia for their technical support. This project is funded by the Government of Malaysia under the Ministry of Higher Learning (Fundamental Research Grant Scheme FRGS/1/2012/SG06/UKM/02/7).

\section{References}

[1] Becker, R., Sivli, J. and Ma Fat, D. (2006) A Method for Deriving Leading Causes of Death. Bulletin of the World Health Organisation, 84, 297-304.

[2] Stefanović-Radić, Z., Comić, L., Radulović, N., Dekić, M., Radojević, V. and Stefanović, O. (2010) Chemical Composition and Antimicrobial Activity of Erodium species: E. ciconium L., E. cicutarium L., and E. absinthoides Willd (Geraniaceae). Chemical Papers, 64, 368-377. http://dx.doi.org/10.2478/s11696-010-0014-x

[3] Weinstein, R.A. (1998) Nosocomial Infection Update. Emerging Infectious Diseases, 4, 416-420. http://dx.doi.org/10.3201/eid0403.980320

[4] World Health Report (2005) Making Every Mother and Child Count. WHO, Geneva, 150-151.

[5] Todar, K. (2002) Antimicrobial Agents Used in the Treatment of Infectious Disease. Textbook of Bacteriology, University of Wisconsin-Madison, 1-11.

[6] Berdy, J. (2012) Thoughts and Facts about Antibiotics: Where We Are Now and Where We Are Heading. The Journal 
of Antibiotics, 65, 385-395. http://dx.doi.org/10.1038/ja.2012.27

[7] Bisht, R., Katiyar, A., Singh, R. and Mittal, P. (2009) Antibiotic Resistance-A Global Issue of Concern. Asian Journal of Pharmaceutical and Clinical Research, 2, 34-39. http://ajpcr.com/Vol2Issue2/189.pdf

[8] Robicsek, A., Jacoby, G.A. and Hooper, D.C. (2006) The Worldwide Emergence of Plasmid-Mediated Quinolone Resistance. The Lancet Infectious Diseases, 6, 629-640. http://dx.doi.org/10.1016/S1473-3099(06)70599-0

[9] Cowan, M.M. (1999) Plant Products as Antimicrobial Agents. Clinical Microbiology Reviews, 12, 564-582. http://cmr.asm.org/content/12/4/564.long

[10] González-Lamothe, R., Gabriel, M., Mariza, G., Moussa, S.D., François, M. and Kamal, B. (2009) Plant Antimicrobial Agents and Their Effects on Plant and Human Pathogens. International Journal of Molecular Sciences, 10, 3400-3419. http://dx.doi.org/10.3390/ijms10083400

[11] Foster, B.C., Arnason, J.T. and Briggs, C.J. (2005) Natural Health Products and Drug Disposition. Annual Review of Pharmacology and Toxicology, 45, 203-226. http://dx.doi.org/10.1146/annurev.pharmtox.45.120403.095950

[12] (1995) World Health Organization Traditional Practitioners as Primary Health Care Workers: A Study of Effectiveness of Four Training Projects in Ghana, Mexico and Bangladesh. WHO, Geneva, 3-5.

[13] Syakirin, F.H., Prasad, K.N., Ismail, A., Yuon, I.C. and Azlan, A. (2010) Antioxidant Capacity of Underutilized Malaysian Canarium odontophyllum (dabai) Miq. Fruit. Journal of Food Composition and Analysis, 23, 777-781. http://dx.doi.org/10.1016/j.jfca.2010.04.008

[14] Prasad, K.N., Chew, L.Y., Khoo, H.E., Yang, B., Azlan, A. and Ismail, A. (2011) Carotenoids and Antioxidants Capacities from Canarium odontophyllum Miq. (dabai) Fruit. Food Chemistry, 124, 1549-1555. http://dx.doi.org/10.1016/j.foodchem.2010.08.010

[15] Basri, D.F., Saidi, N., Mahari, H., Saari, S. and Santhanam, J. (2014) Preliminary Screening for Antimicrobial Activity of The Pulp of Canarium odontophyllum Miq. (Dabai) Fruit. Global Journal of Pharmacology, 8, 213-220.

[16] Basri, D.F. and Fan, S.H. (2005) The Potential of Aqueous and Acetone Extracts of Galls of Quercus infectoria as Antibacterial Agents. Indian Journal of Pharmacology, 37, 26-29. http://dx.doi.org/10.4103/0253-7613.13851

[17] Basri, D.F. and Khairon, R. (2012) Pharmacodynamic Interaction of Quercus infectoria Galls Extract in Combination with Vancomycin against MRSA Using Microdilution Checkerboard and Time-Kill Assay. Evidence-Based Complementary and Alternative Medicine, 2012, Article ID: 493156. http://dx.doi.org/10.1155/2012/493156

[18] Chichioco-Hernandez, C.L. and Paguigan, N.D. (2009) Antimutagenic Potential and Phytochemical Analysis of Selected Philippine Plants. Pharmacognosy Magazine, 5, 388-393. http://www.phcog.com/text.asp?2009/5/20/388/59763

[19] Sahraoui, R., Djellali, S. and Chaker, A.N. (2013) Morphological, Anatomical, Secondary Metabolites Investigation and Physicochemical Analysis of Cistus creticus. Pharmacognosy Communications, 3, 58-63.

[20] Kenari, R.E., Mohsenzadeh, F. and Amiri, Z.R. (2014) Antioxidant Activity and Total Phenolic Compounds of Dezful Sesame Cake Extracts Obtained by Classical and Ultrasound-Assisted Extraction Methods. Food Science \& Nutrition, 2, 426-435.

[21] Hemwimol, S., Pavasant, P. and Shotipruk, A. (2006) Ultrasound-Assisted Extraction of Anthraquinones from Roots of Morinda citrifolia. Ultrasonics Sonochemistry, 13, 543-548. http://dx.doi.org/10.1016/j.ultsonch.2005.09.009

[22] Krishnan, N., Ramanathan, S., Sasidharan, S., Murugaiyah, V. and Mansor, S.M. (2010) Antimicrobial Activity Evaluation of Cassia spectabilis Leaf Extracts. International Journal of Pharmacology, 6, 510-514.

[23] Moshi, M.J., Innocent, E., Masimba, P.J., Otieno, D.F., Weisheit, A., Mbabazi, P., Lynes, M., Meachem, K., Hamilton, A. and Urassa, I. (2009) Antimicrobial and Brine Shrimp Toxicity of Some Plants Used in Traditional Medicine in Bukoba District, North-Western Tanzania. Tanzania Journal of Health Research, 11, 23-28.

http://www.ncbi.nlm.nih.gov/pubmed/19445101 http://dx.doi.org/10.4314/thrb.v11i1.43247

[24] Mogana, R., Khoo, T.J. and Wiart, C. (2011) In Vitro Antimicrobial, Antioxidant Activities and Phytochemical Analysis of Canarium patentinervium Miq. from Malaysia. Biotechnology Research International, 2011, Article ID: 768673. http://dx.doi.org/10.4061/2011/768673

[25] Njume, C., Afolayan, A.J., Samie, A. and Ndip, R.N. (2011) Inhibitory and Bactericidal Potential of Crude Acetone Extracts of Combretum molle (Combretaceae) on Drug-Resistant Strains of Helicobacter pylori. Journal of Health, Population and Nutrition, 29, 438-445. http://www.ncbi.nlm.nih.gov/pmc/articles/PMC3225105/ http://dx.doi.org/10.3329/jhpn.v29i5.8897

[26] Eloff, J.N., Katerere, D.R. and McGaw, L.J. (2008) The Biological Activity and Chemistry of the Southern African Combretacea. Journal of Ethnopharmacology, 119, 686-699. http://dx.doi.org/10.1016/j.jep.2008.07.051

[27] Tan, S.P., Parks, S.E., Stathopoulos, C.E. and Roach, P.D. (2014) Extraction of Flavonoids from Bitter Melon. Food 
and Nutrition Sciences, 5, 458-465. http://dx.doi.org/10.4236/fns.2014.55054

[28] Duhan, J.S., Saharan, P., Surekha and Kumar, A. (2013) Antimicrobial Potential of Various Fractions of Thuja orientalis. African Journal of Microbiology Research, 7, 3179-3186.

[29] Gatsing, D., Nkeugouapi, C.F.N., Nkah, B.F.N., Kuiate, J.R. and Tchouanguep, F.M. (2010) Antibacterial Activity, Bioavailability and Acute Toxicity Evaluation of the Leaf Extract of Alchornea cordifolia (Euphorbiaceae). International Journal of Pharmacology, 6, 173-182.

[30] Konaté, K., Kiendrébéogo, M., Ouattara, M.B., Souza, A., Lamien-Meda, A., Nongasida, Y., et al. (2011) Antibacterial Potential of Aqueous Acetone Extracts from Five Medicinal Plants Used Traditionally to Treat Infectious Diseases in Burkina Faso. Current Research Journal of Biological Sciences, 3, 435-442. http://maxwellsci.com/print/crjbs/v3-435-442.pdf

[31] Nvau, J.B., Gushit, J.S., Orishadipe, T.A. and Kolo, I. (2011) Antimycobacterial Activity of the Leaves Extract of Canarium schweinfurthii Engl. Continental Journal of Pharmaceutical Sciences, 5, 20-24. http://www.wiloludjournal.com/pdf/pharmsci/2011/20-24.pdf

[32] Zhang, L.L. and Lin, Y.M. (2008) Tannins from Canarium album with Potent Antioxidant Activity. Journal of Zhejiang University-Science B, 9, 407-415. http://dx.doi.org/10.1631/jzus.B0820002

[33] Hernandez, N.E., Tereschuk, M.L. and Abdala, L.R. (2000) Antimicrobial Activity of Flavonoids in Medicinal Plants from Taf del Valle (Tucumán, Argentina). Journal of Ethnopharmacology, 73, 317-322. http://dx.doi.org/10.1016/S0378-8741(00)00295-6

[34] Schinor, E.C., Salvador, M.J., Ito, I.Y. and Dias, D.A. (2007) Evaluation of the Antimicrobial Activity of Crude Extracts and Isolated Constituents from Chresta scapigera. Brazilian Journal of Microbiology, 38, 145-149. http://dx.doi.org/10.1590/S1517-83822007000100030

[35] Kannabiran, K., Mohankumar, T. and Gunaseker, V. (2009) Evaluation of Antimicrobial Activity of Saponin Isolated from Solanum xanthocarpum and Centella asiatica. International Journal of Natural and Engineering Sciences, 3, $25-$ 28. http://yeni.kmu.edu.tr/Makaleler/IJNES-Issue\%201-79-2011.pdf

[36] Eloff, J.N. (1998) Which Extractant Should Be Used for the Screening and Isolation of Antimicrobial Components from Plants? Journal of Ethnopharmacology, 60, 1-8. http://dx.doi.org/10.1016/S0378-8741(97)00123-2 
Scientific Research Publishing (SCIRP) is one of the largest Open Access journal publishers. It is currently publishing more than 200 open access, online, peer-reviewed journals covering a wide range of academic disciplines. SCIRP serves the worldwide academic communities and contributes to the progress and application of science with its publication.

Other selected journals from SCIRP are listed as below. Submit your manuscript to us via either submit@scirp.org or Online Submission Portal.
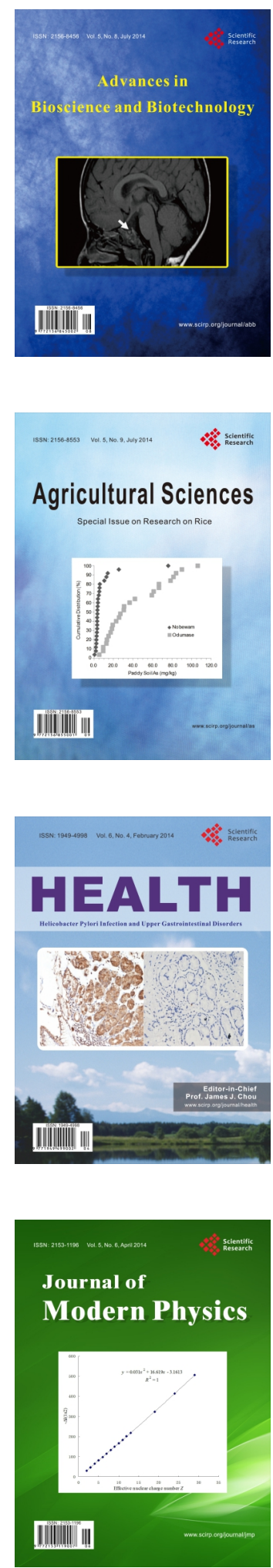
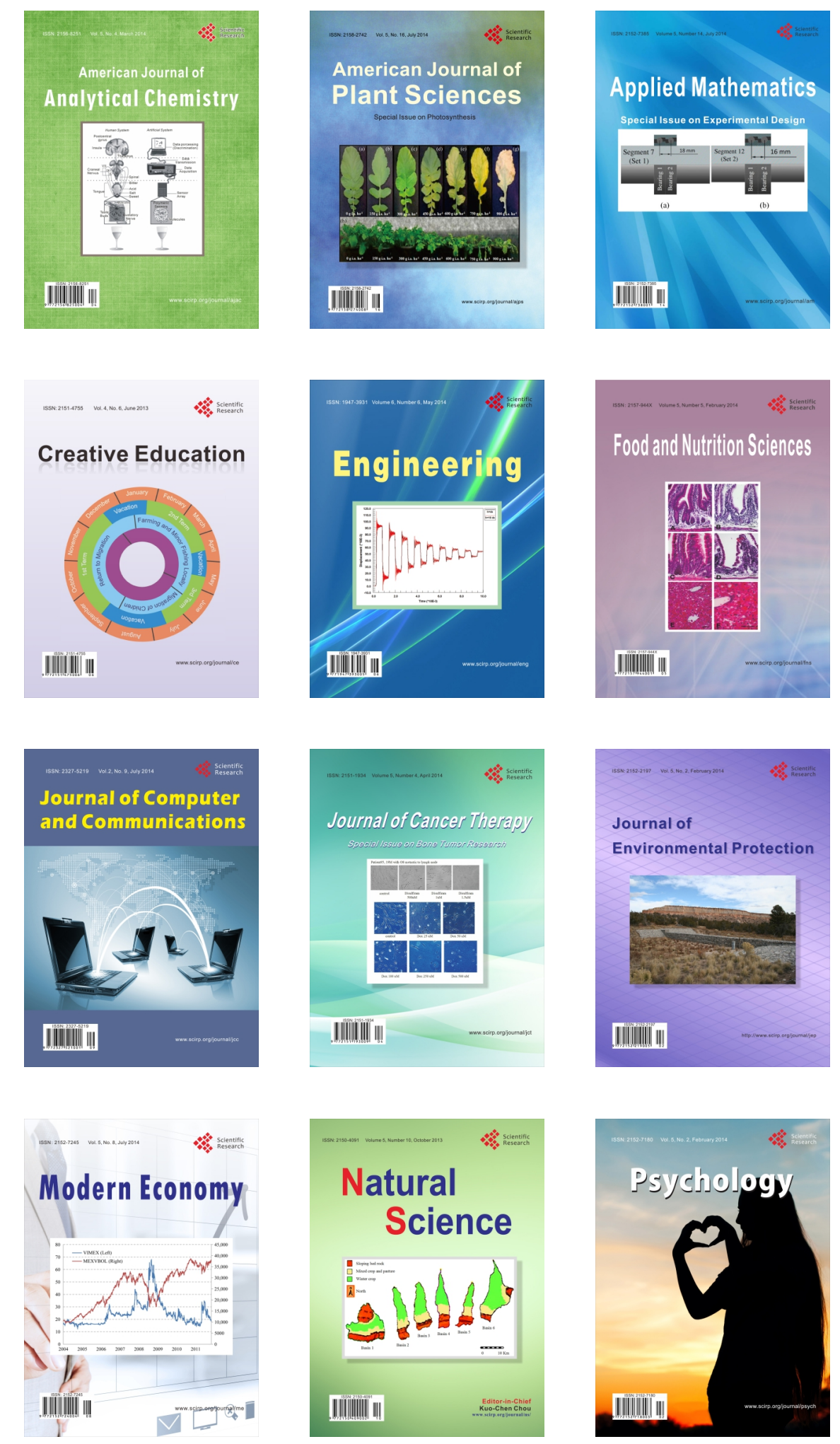